\title{
Pengaruh Pengukuran Intellectual Capital dan Islamicity Performance Index terhadap Kinerja Keuangan
}

\author{
Hani Meilani*, Helliana \\ Bandung, Indonesia. \\ *hanimeilani75@gmail.com, helliana.1969@gmail.com
}

Prodi Akuntansi, Fakultas Ekonomi dan Bisnis, Universitas Islam

\begin{abstract}
Problems in the company's financial performance arise as a result of financial problems related to the survival of the company so that in this case good handling is needed in operational activities in preventing the occurrence of company bankruptcy. The purpose of this study is to be able to examine the effect of measuring intellectual capital and Islamicity performance index on financial performance as measured by ROA. Intellectual capital is measured using the VAICTM method and the islamicity performance index is measured using the profit sharing ratio and zakat performance ratio. This research uses quantitative research. The population in this study is Islamic Commercial Banks registered with the Financial Services Authority for the period 2017-2020 with the sampling technique used is purposive sampling, so that 13 banks are the samples in the study. The research method used is descriptive analysis using a verification method with a quantitative approach. The data analysis method used is multiple linear regression analysis with hypothesis testing to be carried out using IBM SPSS Statistic 23 software. The results of hypothesis testing indicate that intellectual capital partially has a positive and significant effect on financial performance. Profit sharing ratio has a negative and significant effect on financial performance and zakat performance ratio has a positive and insignificant effect on financial performance.
\end{abstract}

Keywords: Intellectual Capital, Profit Sharing Ratio, Zakat Performance Ratio, Financial Performance.

Abstrak. Permasalahan dalam kinerja keuangan perusahaan timbul akibat dari masalah keuangan yang berhubungan dengan kelangsungan hidup perusahaan sehingga dalam hal ini diperlukan penanganan yang baik dalam kegiatan operasional dalam mencegah terjadinya kebangkuran perusahaan. Tujuan dari penelitian ini yaitu untuk dapat memeriksa pengaruh pengukuran intellectual capital dan islamicity performance index terhadap kinerja keuangan yang diukur dengan menggunakan ROA. Intellectual capital diukur dengan menggunakan metode VAICTM dan islamicity performance index diukur dengan menggunakan profit sharing ratio dan zakat performance ratio. Penelitian ini menggunakan penelitian kuantitatif. Populasi yang dilakukan dalam penelitian ini yaitu BUS yang terdaftar di Otoritas Jasa Keuangan tahun periode 2017-2020 dengan teknik pengambilan sampel yang dipakai adalah purposive sampling, sehingga diperoleh 13 bank yang menjadi sampel dalam penelitian. Metode penelitian yang dipakai adalah analisis deskriptif menggunakan metode verifikatif dengan pendekatan kuantitatif. Metode analisis data yang dipakai adalah analisis regresi linear berganda dengan pengujian hipotesis yang akan dilakukan menggunakan software IBM SPSS Statistic 23. Hasil dari pengujian hipotesis menunjukkan bahwa secara parsial intellectual capital memiliki pengaruh positif dan signifikan terhadap kinerja keuangan. Profit sharing ratio memiliki pengaruh negatif dan signifikan terhadap kinerja keuangan dan zakat performance ratio memiliki pengaruh positif tidak signifikan terhadap kinerja keuangan.

Kata Kunci: Intellectual Capital, Profit Sharing Ratio, Zakat Performance Ratio, Kinerja Keuangan. 


\section{A. Pendahuluan}

Permasalahan dalam kinerja keuangan perusahaan biasanya timbul dari masalah keuangan yang berhubungan dengan kelangsungan hidup perusahaan sehingga dalam keadaan seperti ini diperlukan penanganan optimal dalam melanjalankan operasional perbankan demi mencegah terjadinya kebangkuran perusahaan. Sehingga untuk dapat memahami kemajuan perusahaan dari tahun ke tahun, kinerja keuangan tahun sebelumnya dipakai sebagai bahan evaluasi terhadap kinerja perusahaan saat tahun berjalan (Dangnga \& Haeruddin, 2018:61). Kinerja keuangan merupakan gambaran keberhasilan yang dicapai perbankan dengan melihat rasio keuangan melalui informasi dari laporan laba rugi serta laporan posisi keuangan (Sabri \& Suyudi, 2019: 121). Hal tersebut sejalan dengan uraian bahwa kinerja keuangan diartikan sebagai tingkatan keuangan yang dihasilkan oleh perusahaan selama periode yang telah ditentukan mengikuti standar akuntansi atau standar umum yang berlaku (Zarkasyi, 2008: 48).

Dikutip dari finansial.bisnis.com (2021), menurut Doddy Ariefianto pengamat perbankan dari Universitas Bina Nusantara menjelaskan bahwa berdasarkan data dari OJK, sampai dengan data Januari 2021 menampilkan bahwa total aset keuangan bank syariah hanya berkisar pada 9,6\% dari total industri pasar keuangan Indonesia, serta hanya tercatat sebesar $6,4 \%$ dari total aset industri perbankan Indonesia. Sehingga hal ini menjadikan keuangan syariah di Indonesia tidak terolah secara maksimal. Mengacu kepada fenomena yang telah dikemukakan, bahwa kinerja keuangan bank dapat dikatakan sehat atau dalam keadaan baik ketika bank dapat menjalankan fungsi-fungsinya, senantiasa menjaga kepercayaan dari masyarakat, bank dapat berkontribusi dalam menjalankan intermediasi, membantu kelancaran pembayaran dan berkontribusi terhadap kebijakan moneter. Sehingga ketika aspek tersebut dijalankan akan membuahkan suatu sistem perbankan yang kuat dalam mengembangkan perekonomian makro agar untuk dapat memberikan kesejahteraan terhadap masyarakat luas (Dangnga \& Haeruddin, 2018: 45).

Seiiring berkembangnya teknologi, pengetahuan SDM sebagai salah satu elemen berjalannya suatu kompetensi di dalam perusahaan, menciptakan sistem ekonomi baru yang akan dapat mendorong berkembangnya teknologi informasi serta ilmu pengetahuan yang dapat menyebabkan timbulnya Intellectual Capital (Sari, 2021: 476). "Intellectual Capital is a holistic approach to business management and includes human resource management, integrating it in its proper places in the map of value creation in the company" (Roos et al, 2005: 356).

Dalam pengukuran Intellectual Capital, metode $\mathrm{VAIC}^{\mathrm{TM}}$ dipakai sebagai alat ukur untuk menghasilkan nilai tambah dari setiap indikator keberhasilan secara objektif. VAIC ${ }^{\mathrm{TM}}$ menunjukkan kemampuan perusahaan untuk menciptakan nilai mencakup investasi sumber daya seperti, bunga, gaji, dividen untuk pemegang saham, pajak negara, serta investasi dalam periode mendatang. perkembangan. Metode VAIC ${ }^{\mathrm{TM}}$ terdiri atas (1) HCE (Human-Capital), (2) SCE (Structural-Capital), dan (3) CEE (Financial-Capital) (Bounfour \& Eduinsson, 2005: 203). Dalam penelitian ini metode VAIC ${ }^{\mathrm{TM}}$ akan dipakai dalam mengukur Intellectual Capital. Intellectual Capital memiliki relasi dengan variabel terikat yang diukur memakai salah satu indikator yaitu Return on Asset (ROA). Ketika adanya penggunaan Intellectual Capital maka perusahaan pun akan menghasilkan penciptaan nilai tambah yang akan membagikan tanda yang jelas untuk periode mendatang dengan mendorong untuk dapat menaikkan kinerja keuangan melalui penggunaan potensi dalam perusahaan (Hajrawati, 2019: 1).

Selain Intellectual Capital, kinerja keuangan bank syariah salah satunya dapat dipengaruhi oleh Islamicity Performance Index yaitu dengan menguraikan nilai-nilai islam dalam kegiatan bank syariah (Fatmala, 2021: 34). Dalam mengukur Islamicity Performance Index ditemukan 7 rasio yang dapat dioperasikan, diantaranya yaitu (1) PSR (Profit-SharingRatio), (2) ZPR (Zakat-Performance-Ratio), (3) DEWR (Directors-Employees-Welfare-Ratio), (4) EDR (Equitable-Distribution-Ratio), (5) IiIR (Islamic-Income vs Non-Islamic-IncomeRatio), (6) IvIR (Islamic-Investment vs Non-Islamic-Investment-Ratio), dan (7) index AAOIFI (Hameed et al, 2004). Islamicity Performance Index ini dikembangkan dalam menilai kinerja perusahaan, sehingga kinerja tersebut diukur dengan jujur tidak hanya dari financial, tetapi dapat memberikan evaluasi bagaimana prinsip syariat islam diaplikasikan dalam kegiatan perbankan (Hameed et.al, 2004). 
Mencakup fenomena serta latar belakang yang telah dijelaskan, peneliti terdorong untuk dapat menjalankan penelitian dengan memilih judul : "Pengaruh Pengukuran Intellectual Capital dan Islamicity Performance Index Terhadap Kinerja Keuangan" dengan studi empiris pada Bank Umum Syariah (BUS) yang terdaftar di Otoritas Jasa Keuangan periode 2017-2020. Berikutnya, tujuan penelitian ini dapat dirinci ke dalam poin-poin utama, yaitu:

1. Untuk mengetahui pengaruh poitif antara pengukuran Intellectual Capital terhadap kinerja keuangan BUS.

2. Untuk mengetahui pengaruh positif antara Profit Sharing Ratio terhadap kinerja keuangan BUS.

3. Untuk mengetahui pengaruh positif antara Zakat Performance Ratio terhadap kinerja keuangan BUS.

\section{B. Metodologi Penelitian}

Analisis deskriptif menggunakan metode verifikatif dengan pendekatan kuantitatif digunakan sebaga metode yang dipakai peneliti dan software IBM SPSS Statistic 23 dimanfaatkan sebagai alat untuk pengujian hipotesis. Sumber data penelitian yaitu berupa data sekunder berbentuk laporan keuangan dan annual report (laporan tahunan) dari BUS tahun 2017-2020 yang didapat melalui situs remi BUS. Kemudian, teknik pengumpulan data yang dipakai yaitu dengan melakukan pengkajian atau penelusuran terhadap laporan tahunan perbankan yang berhubungan dengan variabel penelitian.

BUS yang telah ada di OJK dijadikan sebagai populasi yang dipakai dalam penelitian. Data daftar BUS tersebut diambil dari data statistik perbankan syariah periode Januari 2017 s.d. Desember 2020. Selanjutnya, untuk pengambilan sampel yang akan diaplikasikan merupakan teknik purposive sampling dengan ketentuan yaitu:

1. BUS yang tercantum di dalam data SPS Otoritas Jasa Keuangan tahun 2017-2020.

2. BUS selalu menyediakan laporan keuangan dalam mata uang rupiah selama tahun 20172020.

3. BUS selalu menyediakan laporan keuangan dan laporan tahunan secara konsisten selama tahun 2017-2020.

Variabel bebas yang dipakai pada yaitu Intellectual Capital sebagai $\mathrm{X}_{1}$ dan Profit Sharing Ratio serta Zakat Performance Ratio sebagai pengukur Islamicity Performance Index $\left(\mathrm{X}_{2}\right)$. Sementara variabel terikat adalah kinerja keuangan $(\mathrm{Y})$.

\section{Intellectual Capital}

Intellectual Capital merupakan aset tetap tidak berwujud (intangible asset) yang memiliki kedudukan penting dalam rangka menaikkan keuntungan perusahaan yang digunakan secara efektif serta untuk dapat menaikkan daya saing dengan perusahaan lain (Salim \& Karyawati, 2013: 3). Intellectual Capital merupakan aset takberwujud yang memiliki manfaat untuk dapat menaikkan nilai dan kompetisi perusahaan (Andriana, 2014: 253). Komponen yang dipakai yaitu terdiri dari tiga bagian:

1. Modal dipakai (Capital Employed/CE) - VACA (Pulic, 2000).

2. Modal manusia (Human Capital/HC) - VAHU (Pulic, 2000).

3. Modal struktural (Structural Capital/SC) - STVA (Pulic, 2000).

\section{Profit Sharing Ratio}

Profit Sharing Ratio merupakan imbal hasil perusahaan. Sehingga rasio ini sangat penting dipakai dalam membantu BUS dalam mencapai target dan sasarannya (Hameed et. al, 2004: 18). Rumus yang dipakai yaitu:

$$
\text { Profit Sharing Ratio }=\frac{\text { Mudharabah }+ \text { Musyarakah }}{\text { Total Pembiayaan }}
$$

\section{Zakat Performing Ratio}

Zakat Performance Ratio yaitu dipakai untuk melakukan perhitungan bersih kekayaan yang dimiliki oleh perusahaan, Jika kekayaan yang dihasilkan perusahaan tinggi maka zakat yang 
dikeluarkan pun akan lebih tinggi (Hameed et. al, 2004: 19). Rumus yang dipakai yaitu sebagai berikut (Hameed et. al, 2004: 19):

\section{Kinerja Keuangan}

$$
\text { Zakat Performing Ratio }=\frac{\text { Zakat }}{\text { Aset Bersih }}
$$

Kinerja keuangan merupakan wujud kesuksesan yang diraih oleh perbankan dengan menggunakan rasio keuangan sebagai informasi dari laporan laba rugi serta neraca (Sabri \& Suyudi, 2019: 121). Return on Asset (ROA) dipakai sebagai indikator untuk perhitungan kinerja keuangan (Dendawijaya, 2009: 118).

Metode pengujian hipotesis yang dipakai yaitu analisis statistik deskriptif. Dalam pengujian hipotesis diperlukan uji asumsi klasik untuk memeriksa hipotesis yang telah dibuat dengan mengaplikasikan ke dalam pemodelan regresi linear berganda, sehingga data bisa dianalisis lebih lanjut tanpa adanya data yang tidak jelas. Uji asumsi klasik terdiri atas:

1. Uji normalitas. Pengujian dilakukan dalam rangka memeriksa apakah dalam penelitian ini memiliki model regresi variabel residual memiliki data yang berdistribusi normal (Ghozali, 2016: 154).

2. Uji multikolinearitas. Memiliki tujuan apakah ketika melakukan pengujian dengan model regresi ini dijumpai ada tidaknya hubungan antar variabel bebas (Ghozali, 2016: 103).

3. Uji heteroskedastisitas. Diaplikasikan untuk dapat memeriksa apakah model regresi yang dipakai tersebut memiliki kesamaan atau tidak terhadap varian dari nilai residual antar pengamat (Ghozali, 2016: 134).

4. Uji autokorelasi. Diaplikasikan untuk dapat memeriksa model regresi linear mempunyai keterkaitan atau tidak antara kesalahan pengganggu dalam tahun tertentu dengan tahun yang sebelumnya (Ghozali, 2016: 107).

Persamaan regresi linier berganda digunakan peneliti diakibatkan variabel bebas yang dipakai lebih dari satu variabel. Persamaan dari regresi linear berganda yang digunakan yaitu:

Keterangan:

$$
\mathbf{Y}=\mathbf{a}+\mathbf{b}_{1} \mathbf{X}_{1}+\mathbf{b}_{2} \mathbf{X}_{2}+\mathbf{b}_{3} \mathbf{X}_{3}+\mathbf{e}
$$

$\mathrm{Y}=$ Kinerja keuangan

$\mathrm{a}=$ Konstanta

$\mathrm{b}_{1}, \mathrm{~b}_{2}, \mathrm{~b}_{3}=$ Koefisien regresi berganda variabel bebas

$\mathrm{X}_{1}=$ Intellectual Capital

$\mathrm{X}_{2}=$ Profit Sharing Ratio

$\mathrm{X}_{3}=$ Zakat Performance Ratio

$\mathrm{E}=$ Standar error

Dalam melakukan pengujian hipotesis, uji yang dipakai diantaranya yaitu:

1. Uji simultan (uji F). Pengujian dilakukan untuk dapat melihat bagaimana variabel terikat dipengaruhi secara bersama oleh variabel bebas (Ghozali, 2016: 96).

2. Uji parsial (uji t). Yaitu uji pengaruh yang menampilkan besar pengaruh dari satu variabel bebas secara tunggal dapat menguraikan perbedaan di dalam variabel terikat (Ghozali, 2018: 98).

Koefisien determinasi dipakai untuk menentukan besarnya pengaruh secara simultan dan secara parsial. Dalam pengaplikasiannya, dapat dirumuskan dengan:

Keterangan:

$$
\mathbf{K d}=\mathbf{R}^{2} \times \mathbf{1 0 0 \%}
$$

$\mathrm{Kd}=$ Koefisien determinasi

$\mathrm{R}=$ Koefisien korelasi

Sedangkan untuk dapat memperhitungkan variabel terikat yang dipengaruh oleh masing-masing dari variabel bebas maka menggunakan koefisien determinasi secara parsial, yaitu dengan memanfaatkan perhitungan rumus Beta dikali dengan Zero Order. 


\section{Hasil Penelitian dan Pembahasan}

\section{Gambaran Umum Unit Analisis}

Jumlah BUS yang terdaftar di OJK tahun 2017-2020 adalah 14 BUS, tetapi tidak semua BUS digunakan sebagai populasi dalam penelitian dikarenakan tidak memeuhi kriteria yang telah ditentukan. Sehingga dalam penelitian ini populasi yang dipakai sebanyak 13 BUS dengan sampel data yang dipakai sebanyak 52 data laporan tahunan BUS. Dari 52 data tersebut, dilakukan pengujian outlier untuk bisa memastikan apakah data yang diproses tidak mengandung data yang ekstrim yang akan menyebabkan informasi yang bias pada hasil penelitian.

Sehingga setelah dilakuka pengujian outlier secara keseluruhan, data sampel yang dihapus dengan menggunakan outlier z score dan outlier Casewise Diagnostics berjumlah 10 data sampel, maka mempengaruhi jumlah data sampel yang mulanya sebanyak 52 data sampel menjadi 42 data sampel yang digunakan untuk mengolah data dalam pengujian selanjutnya.

\section{Analisis Statistik Deskriptif Variabel}

Tabel 1. Hasil Statistik Deskriptif Setelah Penghapusan Outlier

\begin{tabular}{|l|r|r|r|r|}
\hline & Nilai Minimum & $\begin{array}{c}\text { Nilai } \\
\text { Maksimum }\end{array}$ & Nilai Rata-Rata & Standar Deviasi \\
\hline VAIC & $-0,1471$ & 4,8607 & 2,324550 & 1,1733995 \\
\hline PSR & 0,000 & 0,9252 & 0,383314 & 0,2593657 \\
\hline ZPR & 0,000 & 0,0007 & 0,000176 & 0,0002304 \\
\hline ROA & $-0,0126$ & 0,0251 & 0,008929 & 0,0078954 \\
\hline
\end{tabular}

Sumber: Data diolah SPSS, 2022

\section{Pengujian Asumsi Klasik}

a. Uji Normalitas

Tabel 2. Hasil Pengujian Normalitas Sebelum Penghapusan Outlier

\begin{tabular}{|c|c|c|}
\hline & & $\begin{array}{l}\text { Unstandardized } \\
\text { Residual }\end{array}$ \\
\hline \multicolumn{2}{|l|}{$\mathrm{N}$} & 52 \\
\hline \multirow{2}{*}{ Normal Parametersa,b } & Mean & 0,0000000 \\
\hline & Std. Deviation & 0,02986921 \\
\hline \multirow{3}{*}{$\begin{array}{l}\text { Most Extreme } \\
\text { Differences }\end{array}$} & Absolute & 0,199 \\
\hline & Positive & 0.199 \\
\hline & Negative & $-0,146$ \\
\hline \multicolumn{2}{|l|}{ Test Statistic } & 0,199 \\
\hline \multicolumn{2}{|l|}{ Asymp. Sig. (2-tailed) } & $0,000^{\mathrm{c}}$ \\
\hline \multicolumn{3}{|c|}{$\begin{array}{l}\text { a. Test distribution is Normal. } \\
\text { b. Calculated from data. } \\
\text { c. Lilliefors Significance Correction. }\end{array}$} \\
\hline
\end{tabular}

Sumber: Data diolah, 2022

Mengacu pada Data diolah yang ditampilkan di dalam tabel 2, bahwa nilai asymp. sig. (2-tailed) adalah $(0,000<0,05)$, sehingga nilai tersebut menunjukkan data tidak berdistribusi normal serta tidak memenuhi uji normalitas. Sehingga dalam keadaan ini, hal yang harus dilakukan yaitu dengan mengobati data agar menjadi normal, dengan cara melakukan penghapusan data yang outlier atau data yang memiliki nilai ekstrim.

Setelah melakukan pengujian outlier dengan menggunakan nilai $z$ score dan casewise diagnostic untuk menghapus data yang memiliki nilai ekstrim, maka dihasilkan uji normalitas setelah penghapusan outlier yang ditampilkan dalam tabel. 
Tabel 3. Hasil Pengujian Normalitas Setelah Penghapusan Outlier

\begin{tabular}{|c|c|c|}
\hline & & $\begin{array}{l}\text { Unstandardized- } \\
\text { Residual }\end{array}$ \\
\hline $\mathrm{N}$ & & 41 \\
\hline Normal Parametersa,b & Mean & 0,0000000 \\
\hline & Std. Deviation & 0,00418639 \\
\hline Most Extreme Differences & Absolute & 0,133 \\
\hline & Positive & 0,075 \\
\hline & Negative & $-0,131$ \\
\hline Test Statistic & & 0,131 \\
\hline Asymp. Sig. (2-tailed) & & $0,073^{\mathrm{c}}$ \\
\hline $\begin{array}{l}\text { a. Test distribution is Norm } \\
\text { b. Calculated from data. } \\
\text { c. Lilliefors Significance CC }\end{array}$ & ction. & \\
\hline
\end{tabular}

Sumber: Data diolah, 2022

Ditunjukkan bahwa nilai dari asymp. sig. (2-tailed) adalah $(0,073>0,05)$. Sehingga jika dilihat dari nilai tersebut menampilkan bahwa dari data penelitian yang diolah sudah berdistribusi normal serta memenuhi uji normalitas dan dapat dilakukan tahap penelitian yang selanjutnya.

b. Uji Multikolinearitas

Tabel 4. Hasil Pengujian Multikolinearitas

\begin{tabular}{|c|c|c|c|c|c|c|}
\hline \multirow{2}{*}{\multicolumn{2}{|c|}{ Model }} & \multicolumn{2}{|c|}{$\begin{array}{l}\text { Unstandardized- } \\
\text { Coefficients }\end{array}$} & \multirow{2}{*}{$\begin{array}{c}\begin{array}{c}\text { Standardized- } \\
\text { Coefficients }\end{array} \\
\text { Beta }\end{array}$} & \multicolumn{2}{|c|}{ Collinearity-Statistics } \\
\hline & & B & Std. Error & & Tolerance & VIF \\
\hline \multirow[t]{4}{*}{1} & (Constant) & 0,002 & 0,001 & & & \\
\hline & VAIC & 0,002 & 0,001 & 0,394 & 0,892 & 1,121 \\
\hline & PSR & $-0,011$ & 0,004 & $-0,358$ & 0,926 & 1,080 \\
\hline & ZPR & 6,529 & 4,089 & 0,203 & 0,898 & 1,113 \\
\hline
\end{tabular}

Sumber: Data diolah, 2022

Untuk penilaian dari VIF masing-masing memiliki nilai berbeda yaitu VAIC $(1,121<$ 10), PSR $(1,080<10)$, dan ZPR $(1,113<10)$ serta nilai tolerance dari variabel-variabel penelitian dengan nilai VAIC $(0,892>0,1)$, PSR $(0,926>0,1)$, dan ZPR $(0,898>0,1)$. Sehingga dari hasil uji multikolinearitas ini pengujian dapat dilanjutkan ke uji selanjutnya yaitu uji autokorelasi.

c. Uji Heteroskedasitas

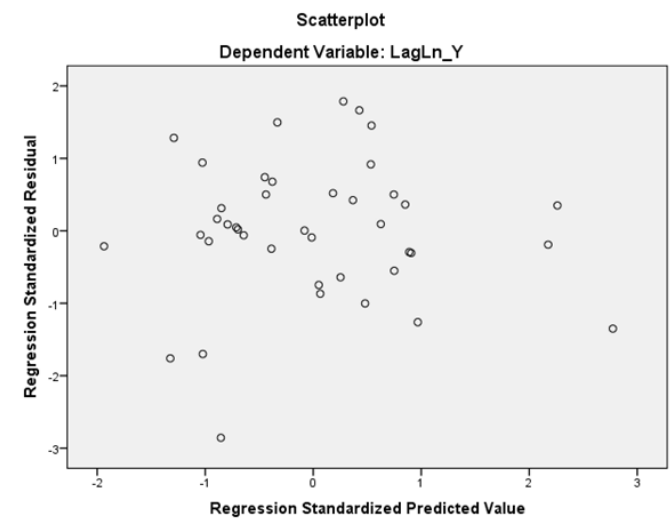

Gambar 1. Hasil Uji Heteroskedasitas

Sumber : Data diolah SPSS, 2022 
Bulir-bulir tersebut menyebar pada sumbu $\mathrm{Y}$ di atas dan di bawah 0 dengan tidak membuat corak pasti dan tidak jelas, sehingga hal ini memperlihatkan bahwa tidak terjadi gejala heteroskedastisitas dalam penelitian. Sehingga dari hasil uji ini dapat dilanjutkan ke pengujian selanjutnya yaitu uji autikorelasi.

d. Uji Autokorelasi

Berdasarkan data yang telah diperhitungkan, nilai DW hitung terletak diantara dU s.d. 4-dU $(1,6061-2,3939)$, yaitu $2,043<1,6061$. Sehingga hasil penelitian ini dipastikan tidak terdapat gejala autokorelasi dan pengujia dapat dipakai untuk melakukan proses selanjutnya.

\section{Analisis Regresi Berganda}

Tabel 5. Hasil Analisis Regresi Berganda

\begin{tabular}{|c|c|c|c|c|c|c|}
\hline & & \multicolumn{5}{|c|}{ Coefficients $^{\mathrm{a}}$} \\
\hline & \multirow[t]{2}{*}{ Model } & \multicolumn{2}{|c|}{$\begin{array}{l}\text { Unstandardized- } \\
\text { Coefficients }\end{array}$} & \multirow{2}{*}{$\begin{array}{c}\text { Standardized- } \\
\text { Coefficients }\end{array}$} & \multirow[t]{2}{*}{$\mathrm{t}$} & \multirow[t]{2}{*}{ Sig. } \\
\hline & & B & Std. Error & & & \\
\hline \multirow[t]{4}{*}{1} & (Constant) & 0,002 & 0,001 & & 1,744 & 0,089 \\
\hline & VAIC & 0,002 & 0,001 & 0,394 & 3,087 & 0,004 \\
\hline & PSR & $-0,001$ & 0,004 & $-0,358$ & $-2,864$ & 0,007 \\
\hline & ZPR & 6.529 & 4.089 & 0.203 & 1.597 & 0.119 \\
\hline
\end{tabular}

Sumber: Data diolah, 2022

Berdasarkan hasil dari tabel coefficients tersebut, dapat ditarik kesimpulan bahwa interaksi yang terjadi diantara variabel bebas dan variabel terikat dirumuskan menjadi:

$$
\begin{gathered}
\mathbf{Y}=\mathbf{a}+\beta_{1} \mathbf{X}_{1}-\beta_{2} \mathbf{X}_{2}+\beta_{3} \mathbf{X}_{3}+\mathbf{e} \\
\mathbf{Y}=\mathbf{0 , 0 0 2}+\mathbf{0 , 0 0 2}\left(\mathbf{X}_{1}\right)-\mathbf{0 , 0 0 1}\left(\mathbf{X}_{2}\right)+\mathbf{6 , 5 2 9}\left(\mathbf{X}_{3}\right)+\mathbf{e}
\end{gathered}
$$

\section{Pengujian Hipotesis}

a. $\quad$ Uji Simultan (Uji F)

Tabel 6. Hasil Uji Signifikansi

\begin{tabular}{|l|l|l|l|l|l|c|}
\hline \multicolumn{2}{|c|}{ Model } & \multicolumn{1}{|c|}{$\begin{array}{l}\text { Sum of- } \\
\text { Squares }\end{array}$} & df & Mean-Square & F & Sig. \\
\hline & Regression & 0,000 & 3 & 0,000 & 10,655 & $0,000^{b}$ \\
Residual & 0,001 & 37 & 0,000 & & \\
& Total & 0,001 & 40 & & & \\
\hline
\end{tabular}

Sumber: Data diolah SPSS, 2022

Uji sign. dari Data diolah menyajikan bahwa nilai sign. $(0,000)$ memiliki nilai yang kecil dari tingkat sign.nya $(0,05)$.

b. $\quad$ Uji Parsial (Uji t)

\begin{tabular}{|c|c|c|c|c|c|}
\hline \multirow{2}{*}{\multicolumn{2}{|c|}{ Model }} & \multicolumn{2}{|c|}{ Unstandardized-Coefficient } & \multirow{2}{*}{$\mathrm{t}$} & \multirow{2}{*}{ Sig. } \\
\hline & & B & Std. Error & & \\
\hline \multirow[t]{4}{*}{1} & (Constant) & 0,002 & 0,001 & 1,744 & 0,089 \\
\hline & VAIC & 0,002 & 0,001 & 3,087 & 0,004 \\
\hline & PSR & $-0,011$ & 0,004 & $-2,864$ & 0,007 \\
\hline & ZPR & 6,529 & 4,089 & 1,597 & 0,119 \\
\hline \multicolumn{4}{|c|}{ a. Dependent Variable: ROA } & & \\
\hline
\end{tabular}

Tabel 7. Hasil Pengujian Parsial (Uji t)

Sumber: Data diolah SPSS, 2022 
Dilihat pengolahan yang ditampilkan dalam tabel 7, menampilkan nilai sign. pada VAIC $^{\mathrm{TM}}$ sebesar $(0,004)<$ tingkat sign. yaitu $(0,05)$. Selain itu, jika melihat dari nilai koefisien dari beta $(\beta) \mathrm{VAIC}^{\mathrm{TM}}$ memiliki nilai positif $(0,002)$.

Dilihat dari tabel 7 , menghasilkan nilai sign. pada PSR $(0,007)$ memiliki nilai yang lebih kecil daripada tingkat sign.nya sebesar $(0,05)$. Selain itu, nilai koefisien beta $(\beta)$ yang tercantum dalam tabel di atas untuk nilai PSR memiliki hasil yang negatif $(-0,002)$.

Dilihat dari tabel 7, memperlihatkan bahwa ZPR memiliki nilai sign. sebesar 0,119. Sehingga jika diperbandingkan dengan tingkat sign.nya $(0,05)$, menghasilkan nilai yang lebih tinggi daripada tingkat sign.nya $(0,119>0,05)$. Selain itu, untuk nilai koefisien beta $(\beta)$ yang tercantum dalam tabel di atas nilai ZPR memiliki nilai yang positif sebesar $(6,529)$.

\section{Pengujian Koefisien Determinasi}

Tabel 8. Hasil Pengujian R-Square

\begin{tabular}{|l|l|l|l|l|}
\hline \multicolumn{1}{|c|}{ Model } & \multicolumn{1}{|c|}{$\mathrm{R}$} & \multicolumn{1}{c|}{ R Square } & $\begin{array}{c}\text { Adjusted R } \\
\text { Square }\end{array}$ & $\begin{array}{c}\text { Std. Error of } \\
\text { the Estimate }\end{array}$ \\
\hline 1 & $0,681^{\text {a }}$ & 0,463 & 0,420 & 0,00435 \\
\hline $\begin{array}{l}\text { a. Predictors: (Constant), ZPR, PSR, VAIC } \\
\text { b. Dependent Variable: ROA }\end{array}$
\end{tabular}

Sumber: Data diolah SPSS, 2022

Berdasarkan Tabel hasil uji $\mathrm{R}^{2}$, menunjukan bahwa besaranya pengaruh secara simultan adalah sebesar 0,463 atau $46,3 \%$.

Tabel 9. Hasil Pengujian Besaran Pengaruh Parsial

\begin{tabular}{|c|c|c|c|c|c|c|c|}
\hline & \multirow{2}{*}{ Model } & \multirow{2}{*}{$\begin{array}{c}\text { Standardized- } \\
\text { Coefficients } \\
\text { Beta }\end{array}$} & \multirow{2}{*}{$\mathrm{t}$} & \multirow{2}{*}{ Sig. } & \multicolumn{3}{|c|}{ Correlations } \\
\hline & & & & & $\begin{array}{l}\text { Zero- } \\
\text { Order }\end{array}$ & Partial & Part \\
\hline \multirow[t]{4}{*}{1} & (Constant) & & 1,744 & 0,089 & & & \\
\hline & VAIC & 0,394 & 3,087 & 0,004 & 0,531 & 0,453 & 0,372 \\
\hline & PSR & $-0,358$ & $-2,864$ & 0,007 & $-0,490$ & $-0,426$ & $-0,345$ \\
\hline & ZPR & 0,203 & 1,597 & 0,119 & 0,389 & 0,254 & 0,192 \\
\hline
\end{tabular}

Sumber: Data diolah SPSS, 2022

Berdasarkan tabel 9, masing-masing dari vaiabel bebas memiliki besar pengaruh secara parsial terhadap variabel terikat:

1. Besarnya pengaruh secara parsial Intellectual Capital yang diukur menggunakan metode VAIC terhadap kinerja keuangan adalah $=0,394 \times 0,531=0,209214(20,92 \%)$.

2. Besarnya pengaruh secara parsial Islamicity Performance Index diukur dengan Profit Sharing Ratio terhadap kinerja keuangan adalah $=-0,358 \times 0,490=-0,17542(17,54 \%)$.

3. Besarnya pengaruh secara parsial Islamicity Performance Index yang diukur menggunakan Zakat Performance Ratio terhadap kinerja keuangan adalah $=0,203 \mathrm{x}$ $0,389=0,078967(7,90 \%)$.

Adapun hasil pengujian terhadap hipotesis yang sebelumnya telah ditentukan dapat diuraikan di bawah ini.

1. Nilai sign. pada VAIC ${ }^{\mathrm{TM}}$ mencapai 0,004. Sehingga ketika nilai sign. tersebut diperbandingkan dengan tingkat sign. $(0,05)$, maka menghasilkan nilai sign.nya memiliki nilai yang lebih kecil daripada tingkat sign.nya yaitu sebesar $(0,004<0,05)$. Untuk nilai koefisien beta $(\beta)$ VAIC $^{\mathrm{TM}}$ memiliki nilai positif sebesar $(0,002)$. Artinya $\mathrm{H}_{1}$ dinyatakan diterima. Sehingga memperlihatkan bahwa Intellectual Capital berpengaruh positif signifikan terhadap kinerja keuangan. Ketika nilai Value Added Intellectual Coefficient $\left(\mathrm{VAIC}^{\mathrm{TM}}\right)$ tinggi maka nilai kinerja keuangan akan semakin tinggi pula.

2. Nilai sign. PSR $(0,007)$. Ini membuktikan nilai sign. dari PSR kurang daripada tingkat sign.nya $(0,005)$. Untuk nilai koefisien beta $(\beta)$ yang tercantum nilai PSR memiliki nilai 
yang negatif $(-0,002)$. Artinya $\mathrm{H}_{2}$ dinyatakan diterima. Maka hal ini memperlihatkan bahwa Profit Sharing Ratio berpengaruh negatif signifikan terhadap kinerja keuangan. Ketika nilai Profit Sharing Ratio tinggi maka nilai kinerja keuangan akan semakin kecil.

3. Nilai sign. dari ZPR memiliki nilai lebih besar daripada tingkat sign.nya yaitu $(0,119>$ $0,05)$. Untuk nilai koefisien beta $(\beta)$ ZPR memiliki nilai yang positif sebesar $(6,529)$. Artinya $\mathrm{H}_{3}$ dinyatakan ditolak.Maka hal ini menampilkan bahwa Zakat Performing Ratio memiliki pengaruh positif tidak signikan terhadap kinerja keuangan. Sehingga semakin tinggi nilai Zakat Performing Ratio, maka nilai kinerja keuangan akan semakin tinggi pula.

\section{Kesimpulan}

Atas dasar dari analisis data yang telah diaplikasikan dapat diraih kesimpulan bahwa:

1. Untuk pengukuran Intellectual Capital $\left(\mathrm{X}_{1}\right)$ berpengaruh terhadap Kinerja Keuangan BUS yang diukur dengan menggunakan ROA. Sehingga ketika Intellectual Capital tinggi maka nilai Kinerja Keuangan akan menjadi tinggi pula.

2. Dalam pengukuran selanjutnya Islamicity Performance Index $\left(\mathrm{X}_{2}\right)$ dengan menggunakan PSR (Profit Sharing Ratio), Profit Sharing Ratio berpengaruh terhadap Kinerja Keuangan BUS. Sehingga semakin tinggi Profit Sharing Ratio, maka Kinerja Keuangan akan semakin menurun.

3. Dalam pengukuran selanjutnya Islamicity Performance Index $\left(\mathrm{X}_{2}\right)$ dengan menggunakan PSR (Zakat Performance Ratio), Zakat Performance Ratio tidak berpengaruh terhadap Kinerja Keuangan BUS.

\section{Acknowledge}

Terima kasih peneliti ucapkan kepada seluruh civitas akademik Universitas Islam Bandung terutama dosen program studi Akuntansi yang telah membimbing dalam menyelesaikan penelitian ini, beserta orang tua yang selalu berkontribusi secara moril maupun materil selama proses perkuliahan dan penelitian, serta rekan seangkatan program studi Akuntansi yang telah memotivasi untuk menyelesaikan penelitian ini.

\section{Daftar Pustaka}

[1] Alfi, Azizah Nur. 2021. Keuangan Syariah Melesat. OJK : Jangan Bangga, Dulu! Masih Banyak Tantangan, tersedia di https://finansial.bisnis.com/read/20210426/231/1386172/keuangan-syariah-melesat-ojkjangan-bangga-dulu-masih-banyak-tantangan [15/11/2021].

[2] Andriana, Denny. 2014. Pengaruh Intellectual Capital Terhadap Kinerja Keuangan Perusahaan (Studi pada Perusahaan Pertambangan dan Manufaktur yang Terdaftar di Bursa Efek Indonesia 2010-2012). Jurnal Riset Akuntansi dan Keuangan, Vol 7 No. 1 pp. 251-260.

[3] Bounfour, Ahmed \& Leif Edvinsson. 2005. Intellectual Capital for Communities Nations, Regions, and Cities. Oxford: Elsivier Ltd.

[4] Dangnga, Muh, Taslim \& M. Ikhwan Maulana Haeruddin. 2018. Kinerja Keuangan Perbankan: Upaya Untuk Menciptakan Sistem Perbankan yang Sehat. Makassar: CV. Nur Lina.

[5] Dendawijaya, Lukman. 2009. Manajemen Perbankan. Bogor: Ghalia Indonesia.

[6] Fatmala, Kiki. 2021. Pengaruh Islamicity Performance Index dan Islamic Social Reporting terhadap Kinerja Keuangan Perbankan Syariah di Indonesia. Invoice: Jurnal Ilmu Akuntansi, Vol. 3 No. 1 pp. 30-43.

[7] Ghozali, Imam. 2016. Aplikasi Analisis Multivariat dengan Program IBM SPSS. Edisi 7. Semarang: Badan Penerbit Universitas Diponegoro.

[8] Hajrawati. 2019. Pengaruh Intellectual Capital Terhadap Kinerja Keuangan Pada Bank di Bursa Efek Indonesia. EQUITY: Jurnal Ekonomi, Manajemen dan Akuntansi, Vol 14 No. 1 pp. 1-8. 
[9] Hameed, Shahul et. al. 2004. Alternatif Disclosure \& Performance Measures for Islamic Banks. Malaysia: Departmen of Accounting.

[10]Nurdin, Sabri \& Muhammad Suyudi. 2019. Pengaruh Intellectual Capital dan Islamicity Performance Index Terhadap Kinerja Keuangan Perbankan Syariah di Indonesia. Jurnal Akuntansi Multi Dimensi (JAMDI), Vol. 2 No. 2 pp. 119-127

[11] Pulic. 2000. VAIC - An Accounting Tool for IC Management. International Journal of Technology Management Vol. 20 No.5 pp. 702-714.

[12]Roos, Goran et. al. 2005. Managing Intellectual Capital in Practice. Oxford : Elsevier Ltd.

[13] Sari, Amalia Paramita. 2021. Pengaruh Intellectual Capital Terhadap Kinerja Keuangan pada PT. Bank Rakyat Indonesia dan PT. Bank Negara Indonesia. Ekonomis: Journal of Economics and Business, Vol. 2 No. 2 pp. 476-480.

[14] Zarkasyi, Moh, Wahyudin. 2008. Good Corporate Governance, Pada Badan Usaha Manufaktur, Perbankan, dan Jasa Keuangan Lainnya, cetakan kesatu, Penerbit : Alfabeta, Bandung. 